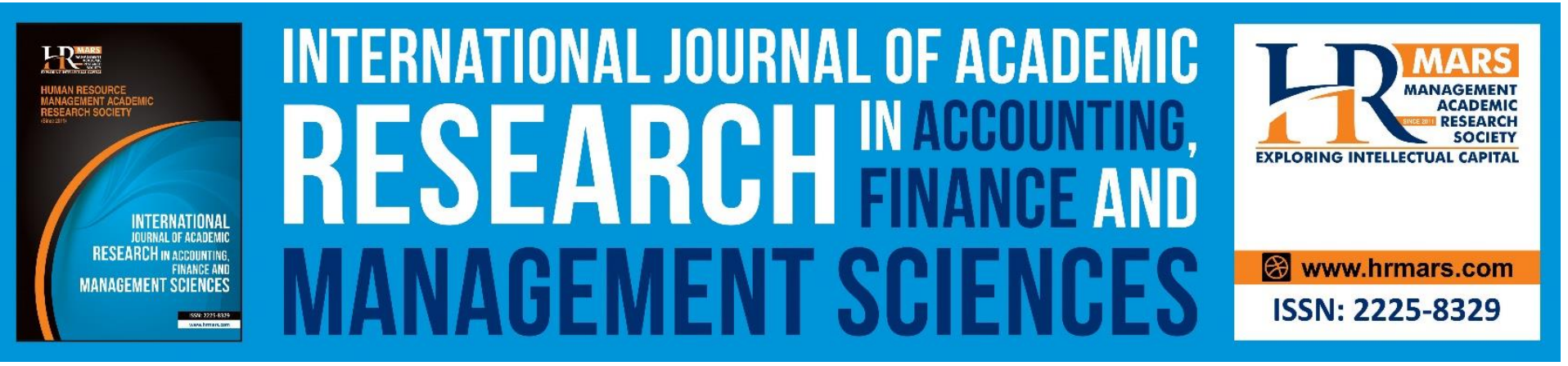

\title{
The Impact of Non-Current Assets on the Performance of Firms in Malaysian Construction Sector
}

\section{Razman Bin Anuar, Mohamad Bin Jais, Michael Tinggi}

To Link this Article: http://dx.doi.org/10.6007/IJARAFMS/v11-i1/8598

DOI:10.6007/IJARAFMS /v11-i1/8598

Received: 10 December 2020, Revised: 11 January 2021, Accepted: 29 January 2021

Published Online: 16 February 2021

In-Text Citation: (Anuar et al., 2021)

To Cite this Article: Anuar, R. Bin, Jais, M. Bin, \& Tinggi, M. (2021). The Impact of Non-Current Assets on the Performance of Firms in Malaysian Construction Sector. International Journal of Academic Research in Accounting Finance and Management Sciences, 11(1), 57-79.

Copyright: (C) 2021 The Author(s)

Published by Human Resource Management Academic Research Society (www.hrmars.com)

This article is published under the Creative Commons Attribution (CC BY 4.0) license. Anyone may reproduce, distribute, translate and create derivative works of this article (for both commercial and non-commercial purposes), subject to full attribution to the original publication and authors. The full terms of this license may be seen

at: http://creativecommons.org/licences/by/4.0/legalcode

\section{Vol. 11, No. 1, 2021, Pg. 57 - 79}

Full Terms \& Conditions of access and use can be found at http://hrmars.com/index.php/pages/detail/publication-ethics 


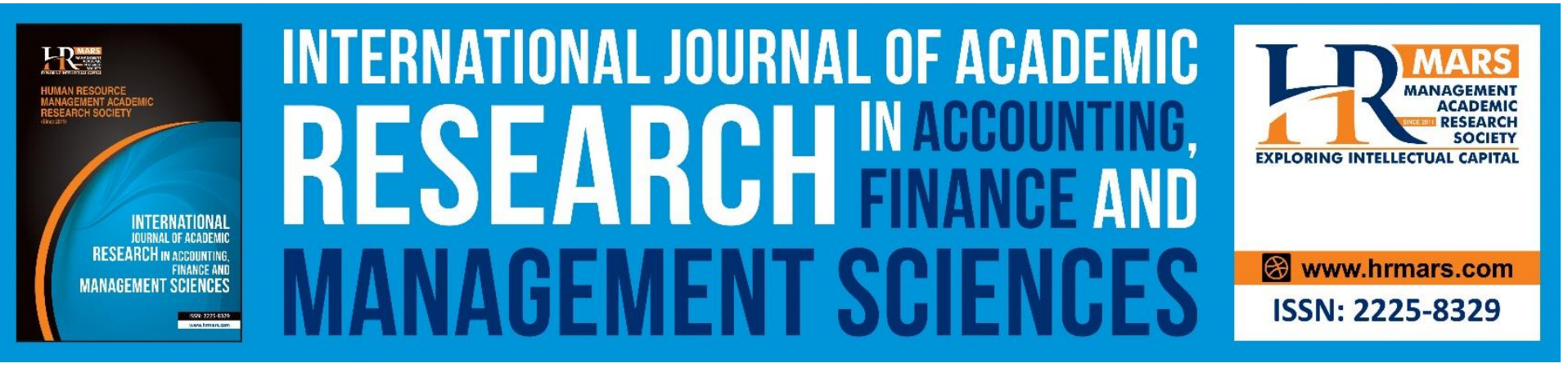

\title{
The Impact of Non-Current Assets on the Performance of Firms in Malaysian Construction Sector
}

\author{
Razman Bin Anuar, Mohamad Bin Jais, Michael Tinggi \\ Faculty of Economics and Business, Universiti Malaysia Sarawak, Kota Samarahan, Sarawak. \\ Email: razzoes@gmail.com
}

\begin{abstract}
The aim of this study is to investigate on the relationship between non-current assets (NCA) for construction firms listed in Bursa Malaysia with firms' performance. The efficiency of the firms' NCA is measured by fixed assets turnover, asset tangibility, and total assets turnover mated with return on assets (ROA) and return on equity (ROE), both proxies for firms' performance. The data collected and analysed in this research focused on the construction sector listed firms under Bursa Malaysia covering the period of 2011 to 2017. The methods employed in this research include descriptive analysis, correlation analysis, and fixed effects model to examine the research objectives. The quality of the data is tested by applying normality, multicollinearity, heteroscedasticity, and auto-correlation tests. The results of this study reveal that the fixed asset turnover (FATO) in the construction sector has a significant positive impact on both ROA and ROE. On the other hand, the total assets turnover (TATO) has a significant positive impact only on ROE while asset tangibility (ASTA) has no impact at all on both ROA and ROE. These findings are useful for governments, policymakers, and other stakeholders to develop effective policies, rules, or regulations in promoting economic productivity, growth, and best financing decision.
\end{abstract}

Keywords: Construction, Fixed Assets Turnover, Asset Tangibility, Total Assets Turnover, Firms Performance

\section{Introduction}

There is a wealth of literature by scholars and practitioners on the challenges facing the construction industry internationally. The increased rate of failure and poor performance of contractors in the sector are triggered by the minimal investment in NCA, i.e. the collateral used in settling financing obligation during crisis (Cannon \& Hillebrandt, 1989; Chiang et al., 2002). Ofori (2000) mentioned that the underinvestment of NCA by contractors was due to the effect of globalisation and advancements in technology in the changing economic environment. For the Malaysian construction industry $(\mathrm{MCl})$, gaps have always been highlighted in various literature reviews in the local or and international journals, conferences, and conventions. Based on the local study it could be summed up that $\mathrm{MCl}$ 
INTERNATIONAL JOURNAL OF ACADEMIC RESEARCH IN ACCOUNTING, FINANCE AND MANAGEMENT SCIENCES

Vol. 11, No. 1, 2021, E-ISSN: 2225-8329 @ 2021 HRMARS

was full of delays in the approval of projects, incomplete projects, cost overruns, late payment to contractors, poor quality of work resulting in the negative reputation of the firms in the industry, lack of training and sluggish implementation of technology. Endut et al. (2009); Rahman et al. (2013) concluded that Malaysian construction firms faced huge cost overruns in projects due to the ineffective management, including poor material control, poor site management and poor cash management which have caused a bad image to the industry. The Construction Industry Development Board (CIDB) Master Plan for Occupational Safety and Health (CIDB Master Plan OSHA, 2004) highlighted significant issues related to quality, productivity, image, economic instability, delays, labour shortages, insufficient data and poor knowledge. Low productivity in the industry is attributed by the low technology used, poor project and site management, employment of unskilled labour, high input and length projections, manpower shortages, high construction waste, inadequate maintenance, non-conducive and disaster-prone conditions. This had dented the image of the industry due to high number of accidents at site, the absence of job security, poor management, and high risks jobs with low wages and poor opportunity in job progress. Another weak point of the industry is the lack of organised and structured training and skills training in the field. Unlike other sectors, construction has seen little or no change in efficiency over the last eight decades. Ameh et al. (2010); Frimpong et al. (2003); Shehu et al. (2014) pointed out that the poor skills in communicating with relevant parties, technical know-how especially on the site has not improved as contractors are still using the methods used in the earlier construction era, as contractors based on their experiences rather than learning formally. This confrontational condition creates a massive imbalance between those planning, designing (the architectural and engineering), taking off amounts and preparing paperwork (the consultants), and those organizing, implementing, and executing building improvement projects (the contractors). Ameh et al. (2010); Shehu et al. (2013) discovered that the entire construction industry is notoriously slow to adopt the emergence of new technologies. Throughout the years, numerous surveys and studies have shown that business owners tend to underinvest in technology, despite their acknowledgment of the advantages of technology advancement to run their business and handle construction projects. Construction firms fail to tap the technology benefits, causing firms fail to gain the competitive advantage over local and international competitors. Considering the above weaknesses and significant gaps in the construction industry of Malaysia, this study intends to bridge the conflict of findings in the assets structures of construction firms through investigating mainly on the impact of NCA that affects firms' performance. The general objective of this study is to examine the impact of firm's NCA on firms' performance of the construction sector in Malaysia. The measures for the NCA in this study are FATO, ASTA and TATO. Therefore, this study seeks for the answers that are aimed to be justified through this research questions which includes:

1. Does the fixed asset turnover give a significant effect on ROA and ROE?

2. Is there any significant influence of asset tangibility on ROA and ROE?

3. How does the total asset turnover affect ROA and ROE?

Subsequently, the following specific objectives have been established to answer the research questions and achieved the aim of this study:

1. To investigate the effect of fixed asset turnover on the performance of firms.

2. To examine the relationship between asset tangibility the performance of firms.

3. To assess the impacts of total asset turnover on the performance of firms. 
INTERNATIONAL JOURNAL OF ACADEMIC RESEARCH IN ACCOUNTING, FINANCE AND MANAGEMENT SCIENCES

Vol. 11, No. 1, 2021, E-ISSN: 2225-8329 @ 2021 HRMARS

This study makes a significant contribution to governments, policymakers, and other stakeholders develop effective policy, rules, or regulations to promote economic productivity, growth, and stable finance. It makes sure that the interest of shareholders and stakeholders are in the same line and treated fairly and also facilitate the company to involve in long- term investment. Further, regulatory bodies such as the Department of Occupational Safety and Health (DOSH), a department under the Ministry of Human Resources can use these findings to enhance the framework for ensuring the safety, health, and welfare of people at work as well as protecting other people from the safety and health hazards arising from the activities in the construction sector. Findings from this study would offer critical input for interested parties by providing better insight for making business decisions. Through this study, the management will be able to strategize and optimize the utilisation of their NCA on achieving the desired profitability, growth, planning, and formation of business strategies, as well as addressing the liquidity challenges and ultimately to avoid firms from possible insolvency. As for academicians, this study would provide in-depth information by providing important materials and sources for future study in the related area. Therefore, this study adds a novelty where many other researchers have not been able to explore.

\section{Literature review}

\section{Asset Management Efficiency and Firms' Performance}

Assets have significant function to determine the profitability of a firm and is the crucial elements to determine the profit ratio (Smith, 1980). The Malaysian Financial Reporting Standards (MFRS) 116 states that assets are the probable future economic benefits obtained or controlled by a particular entity as a result of past transaction or events. There are various kind of reasons why the study of assets is considered to be the most important exercise to a firm. In principle, there are two types of assets in the commercial firms which is current asset and non-current assets. The current assets are short-term assets. These resources are expected to be used to benefit a company within a year (twelve months' period) or the current accounting period. Common examples of current asset are cash, inventory, account receivables and prepaid expenses. Undeniable, these assets are the life blood of every firm (Flanagan, 2005). However, for the purpose of this research study, the focus is on NCA. Therefore, current assets will not be described in detail. Lzryadnova (2013) stated that the investments in NCA at large and medium-sized firms in Oman exceeds 90 percent for the investments amount proves that the acquisition of NCA involves high capital outlay. Iqbal and Mati (2012) stated that efficient organization of NCA is the core segment of the entire firm and initiate the value of shareholders.

\section{Fixed Assets Turnover Ratio (FATO)}

FATO is an effective method used by financial statement users to gauge the firm's ability in utilising its NCA to generate revenue. Basically, higher FATO indicates better utilisation of NCA that that enables the firm to achieve its goals, i.e. high revenue and high profitability (Balatbat et al., 2010; Brigham, 1995; Chowdhury \& Chowdhury, 2010; Fraser \& Ormiston, 2004; Ramamonjiarivelo, 2016; Sunjoko \& Arilyn, 2016). The effective use of NCA of firms are formed on the basis of the ratio of an integrated indicator of the efficiency of the use of the company's fixed production assets through the standardization of single efficiency indicator, i.e. FATO (Gajfullina et al., 2017). Al-Ani (2013) and Warrad and Rania (2015) studied on the impact of assets turnover and FATO against ROA for Jordanian and Sultanate of Oman firms and discovered that a significant relationship between assets 
INTERNATIONAL JOURNAL OF ACADEMIC RESEARCH IN ACCOUNTING, FINANCE AND MANAGEMENT SCIENCES

Vol. 11, No. 1, 2021, E-ISSN: 2225-8329 ๑ 2021 HRMARS

turnover and FATO against ROA existed. They concluded that the assets activity ratios explain the changes in the ROA and the ratios have significant impact for the country's industrial sector's performance. Iqbal and Mati (2012) concluded that FATO has a positive relationship against ROA. Sunjoko and Arilyn (2016) added that TATO however does not affect firms' profitability. Contrarily, Harianto (2017), discovered that FATO has a negative but insignificant influence over ROA for the information technology product companies in Indonesia. Iqbal and Mati (2012) established that FATO has a positive relationship against ROE. Al-Ani (2013) ascertained the existence of impact between assets turnover and FATO on ROE for the study conducted in the Sultanate of Oman manufacturing firms. Popa and Ciobanuwe (2014) verified the influence of FATO, turnover, price earnings ratio, duration of current assets by turnover and leverage over ROE for SME's in Romania. Harianto (2017), discovered that FATO has a positive and significant influence over ROE for the information technology product companies in Indonesia. It has been concluded the coefficient of fixed asset turns tends positive towards gross profit margin in most of the non-financial companies as compared to other profitability ratios like ROA and ROE. Therefore, the first hypothesis is developed as;

\section{H1: There is a positive significant relationship between FATO and firms' performance.}

\section{Asset Tangibility (ASTA)}

There are many reasons why the ASTA is considered important in this research study. First, excessive tangible assets were negatively related to profitability because of the expensive maintenance inherent with these assets. This assumption is based on the prior research studies reported that investment in tangible assets may have an important effect on the firm's profitability and may have a negative correlation. This means that the high proportion of NCA lessen the financial performance (Onaolapo \& Kajola, 2010; Zeitun \& Tian, 2007). High levels of tangible assets reduced profitability due to less sales variation, low in research and development exercise and bring down the investment opportunities in the long run (Kebewar, 2013), thus concluding to a negative relationship between tangibility and firm's profitability. Mehmet and Mehmet (2018) examined the influence of financial characteristics on the profitability of energy firms listed on Borsa Istanbul Stock Exchange. Quarterly (2008:Q1-2015:Q4) panel data of 10 quoted energy firms was employed for the study. The multiple regression analysis of the study showed that the tangibility of the ratio of tangible assets to total assets had a substantial negative impact on the profitability of the firms as calculated by ROA. Unlike the above scholars, the coefficient of tangible asset tends to be positive in most of the non-financial companies when gross profit margin (GPM) is used as a proxy of performance instead of profitability ratios like ROE and ROA (Iqbal \& Mati, 2012). This is unlike the findings by Pouraghajan and Malekian (2012) where asset turnover and tangible asset structure are statistically and positively correlated with ROE and ROA for the period 1998 to 2012. Odusanya et al. (2018) analysed the determinants of financial performance of 114 companies listed on the Nigerian Stock Exchange and found that assets tangibility had an insignificant impact on the profitability of the businesses through the Generalized Moment Method (GMM) methodology of data analysis. Adversely, some other researchers discovered that the investments in tangibles assets do not strongly and significantly impact on the level of reported profit (Okwo et al., 2012). On an extreme note, Masood, et al. (2017) opined that in the existing business landscape, tangible assets like land and labour are said to be no longer significant as a determinant for business performance. Instead, only organizational asset and reputational asset i.e. intangible assets are relevant and significant. Based on the above literature, 
INTERNATIONAL JOURNAL OF ACADEMIC RESEARCH IN ACCOUNTING, FINANCE AND

MANAGEMENT SCIENCES

Vol. 11, No. 1, 2021, E-ISSN: 2225-8329 @ 2021 HRMARS

this research study anticipate that ASTA would have an important effect and the second hypothesis is constructed as;

H2: There is a positive significant relationship between ASTA and firms' performance.

\section{Total Asset Turnover Ratio (TATO)}

Total Asset Turnover Ratio (TATO) is a ratio often used in gauging the assets turnover of a firm, in terms of the return per ringgit invested in securing the assets (Irman et al., 2020; Padachi, 2006). In other words, TATO enables the user of financial statements to measure the assets ability in generating revenue (Babalat et al., 2010). Higher TATO is desired by firm as it marks the proper asset management, optimisation on the asset potential benefits whilst scoring high TATO and ROA (Irman et al., 2020). Interestingly, Jumahana (2017) and Rahmah et al. (2016) stated that TATO has a significant negative effect on ROA. However, this statement contradicts with the results obtained by Irman et al. (2020) and Putry and Erawati (2013) i.e. TATO has a significant positive effect on ROA. AlAni (2013) reported that TATO and ROA have a significant and positive relationship for the research done in the Sultanate of Oman. TATO has a significant positive effect on ROA, which means that the higher the TATO, the higher return on assets and vice versa (Irman et al., 2020). Babalat et al. (2010), discovered that the Australian's construction firms have a below average TATO as compared to other international construction and engineering firms. Thus, from the above discussion, the final hypothesis is developed as;

\section{H3: There is a positive significant relationship between TATO and firms' performance.}

\section{Theoretical Models}

There are four types of theoretical assumptions related to this research study such as agency theory, stewardship theory, stakeholder's theory and pecking-order theory.

\section{Agency theory}

Blair (1995) mentioned that this theory upholds the maximising of profits which leads to the increase of shareholders' wealth. Thus, Pavlik et al. (1993) advocates that the assessment and rewards must rely more than one performance measurement as well as taking into consideration other measures responsive to the results.

\section{Stewardship theory}

Davis et al. (1997), Nguyen (2020) and Zahra et al. (2008) mentioned that this concept emphases in the achieving goals and dominating the business activities, focusing on the owner and agent relationship, thus it differs them the agency theory. This theory presumes that agent (executive) fancies to serve the organisation goals rather than satisfying personal economic desires, and accomplishing the mission and vision the organisation. Davis et al. (1997) added that the stewardship actions are boosted by the presence of authoritarian type of leaders, and performed better when compared to an agency-based leadership underlining the control over the financial matters. Organisations collaborating a mix of functional and culture are able to demonstrate strategic flexibility (Puig et al., 2005; Worren et al., 2002). Association with investors transpire only in situations with the existence of specific organisation structure, with the earlier act with proper psychosomatic profile and risk inclinations, thus this theory is the adversary of the agency theory that is dependent on the control and supervision elements (Davis et al., 1997). 
INTERNATIONAL JOURNAL OF ACADEMIC RESEARCH IN ACCOUNTING, FINANCE AND

MANAGEMENT SCIENCES

Vol. 11, No. 1, 2021, E-ISSN: 2225-8329 @ 2021 HRMARS

\section{Stakeholder's theory}

In the earlier stages, this theory describes stakeholders as person/s may affect or be affected by the accomplishments of organisations' objectives (Freeman, 1984). However, in 2004, Freeman delineates stakeholders as group of individuals essential to the going concern of a corporation, i.e. they have the option of taking action against the directors for departing from performing the responsibilities with due care. Jamali (2008), added that greater performance would be achieved when the stakeholders are in the loop of networking and communication, when compared to the emphasis on the effort of maximising profits.

\section{Pecking Order Theory}

The principle of pecking order indicates firms have a specific order of choice for money used to fund their businesses (Myers \& Majluf, 1984). The corporation would favour retained earnings over debt, short-term debt to long-term debt, and debt to equity, owing to the information asymmetries between the business and future investors. Chen et al. (2011) concluded that if firms only use its retained earnings instead of issuing new security to support the investment opportunities, the information asymmetric can be resolved. That means issuing equity becomes costlier as the insiders and outsiders of asymmetric information expand. Companies that have a significant asymmetry of information will issue debt to prevent the selling of under-priced securities. The rising capital structure of events such as new stock offering contributes to a fall in stock prices for a company. Insider investors prefer to restrict the use of equity to maintain ownership of the company (Hutchinson, 1995). Managers will choose internal finance such as retained earnings relative to external finance. In extreme situations, firms will select the external funds, but debt financing is the first choice before convertible securities the next and the equity issuance is the last option (Myers, 1984). Myers (2001), revealed that this theory clarifies why high-profit companies are less dependent on debt funding as these companies have more internal financing available for capital investments rather than a low debt ratio target. The pecking order theory is applied by firms with low profitability by issuing more debt when the internal funds provided are insufficient. This proposed theory is supported with studies by Agyei and Owusu (2014); Chen et al. (2011); Fama and French (2002); Nguyen (2019). They found a negative association between profitability and decision on financing that is consistent with such theory. Apparently, these results have obviously shown that the performance of the company has an impact on the leverage decision.

Figure 1 is the theoretical model to support the four type of theories described in the above. The selected three independent variables are FATO, ASTA and TATO while firms' performance (dependent variable) were indicated by ROA and ROE. Another two controlled variables also been selected which are firms' size (SIZE) and financial leverage (FLEV). 
INDEPENDENT VARIABLES (IV)

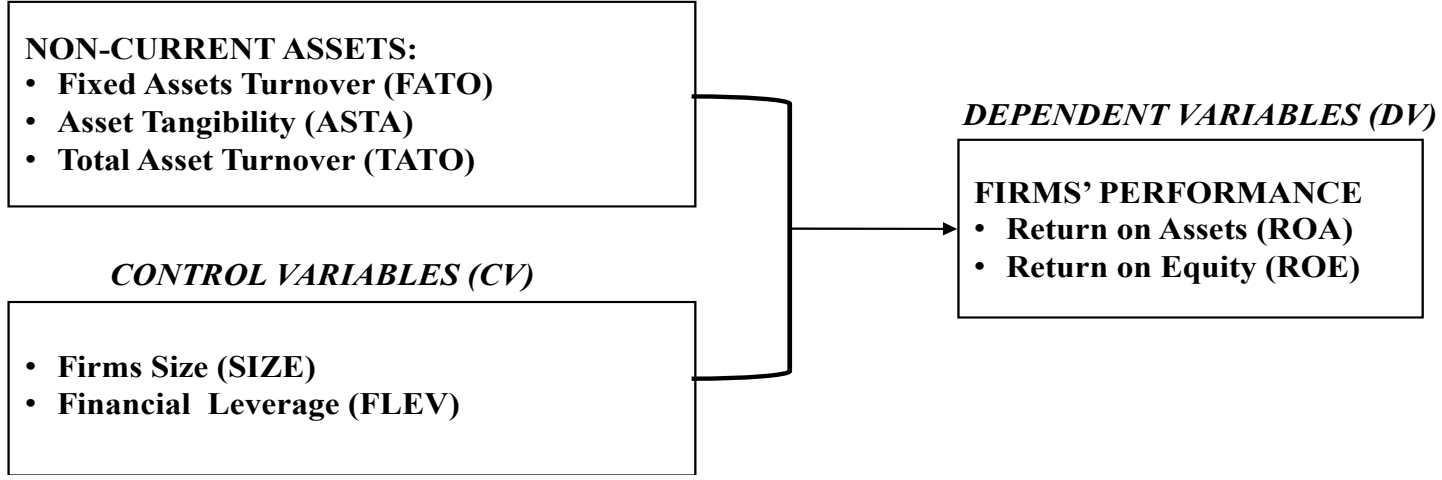

Figure 1: Theoretical Model

\section{Methodology of Research}

This study implements a quantitative study because the main purpose is to test the hypotheses in numerical measurement by integrating reviews of the preceding literature to solve the research questions that have been created. The sample data were obtained from DataStream, the website of Bursa Malaysia and the company's annual report. The period for the panel data regression is over seven years from 2011 to 2017. The dependent variable is ROA and ROE while the three independent variables are FATO, ASTA and TATO. The relationship between firms' performance and the selected NCA variables was evaluated using the regression model for panel results. This study used two output metrics of the dependent variable as a measure of performance, which are ROA and ROE, the most widely and common proxies used as indicators relied on in most previous research. The following regression models were based on Abdel Shahid (2003), Abor (2005), Ang et al. (2000), Ebaid (2009), Saedi and Mahmoodi (2009) and Tian and Zeitun (2007) expressed as follows:

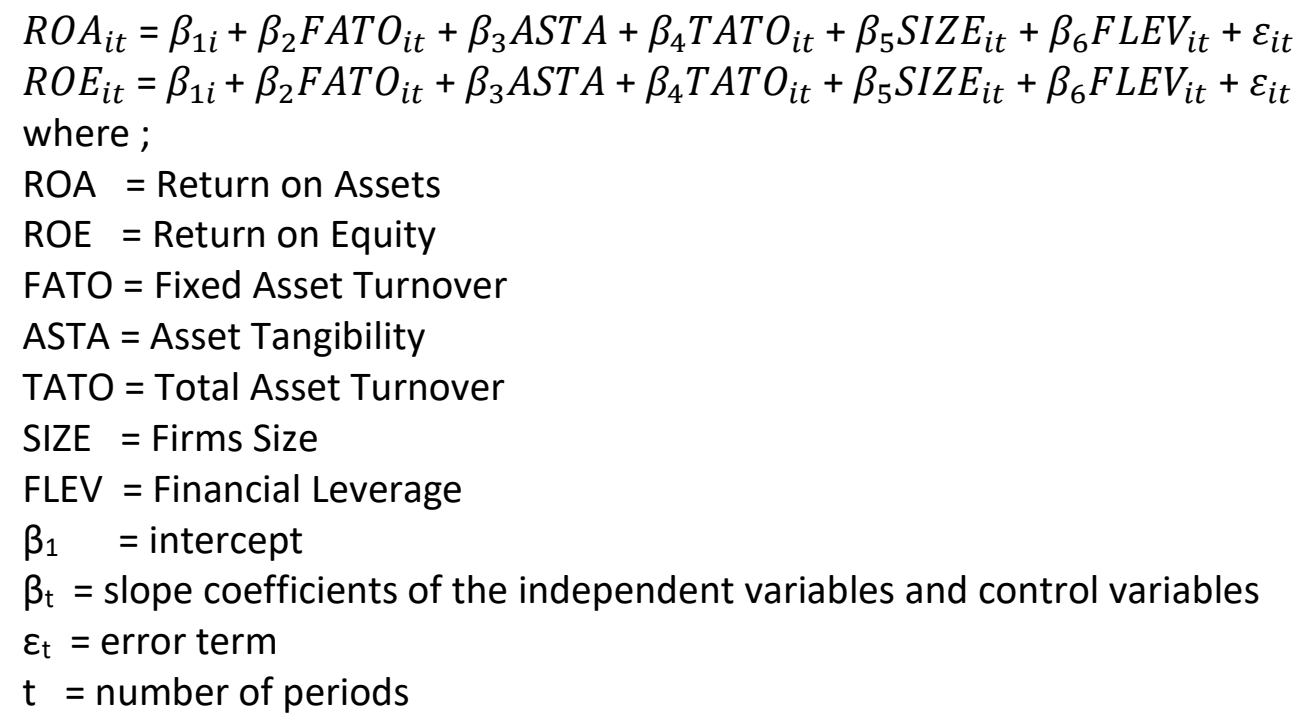

The linear transformed form is used in this study to estimate the connection for ROA, ROE, FATO, ASTA and TATO. The performance of ROA and ROE are affected by the movement of FATO, ASTA and TATO. In other words, the change in either of the independent variables will cause the ROA and ROE to change. ROA is measured by dividing the net income to the total assets while ROE is calculated by 
INTERNATIONAL JOURNAL OF ACADEMIC RESEARCH IN ACCOUNTING, FINANCE AND MANAGEMENT SCIENCES

Vol. 11, No. 1, 2021, E-ISSN: 2225-8329 @ 2021 HRMARS

dividing the net income over the shareholders' equity. The independent variable for FATO is calculated by dividing the sales to the average NCA. ASTA is calculated as the ratio of average NCA to average total assets and TATO is calculated using the sales divided by average total assets. In testing and analysing the data gathered, a descriptive statistic, correlation and coefficient analysis and panel regression analysis were used which includes the Pooled Ordinary Least Square (OLS), Random Effect Model, Fixed Effect Model. These models were tested with the diagnostic tests consists of the JarqueBera normality test, Variation Inflation Factor (VIF) Multi-correlation test, heteroscedasticity White Test and Durbin Watson Autocorrelation test. In selecting the best model that suits the data set, tests include the Breusch Pagan Lagrangian Multiplier test (in choosing either the Pooled Ordinary Least Square (OLS) or Random Effect Model) and the Hausman test for opting either the Random Effect Model or the Fixed Effect Model.

\section{Findings}

\section{Descriptive Statistics}

Table 1 illustrates ROA as a proxy of profitability has an average value of 3.42 percent, with a maximum of 23.73 percent to the lowest of -8.33 percent and is positively skewed and show that the construction sector is recording a positive overall performance despite of low in value. ROE has a mean of 5.83 percent, with the maximum value recorded at 36.70 percent and the lowest value at 10.62 percent and overall denotes that denotes that generally construction firms are able to give returns to the shareholders on their investments.

Table 1: Descriptive Analysis

\begin{tabular}{lccccccc}
\hline \hline & ROA & ROE & FATO & ASTA & TATO & SIZE & FLEV \\
\hline \hline Mean & 0.034147 & 0.058283 & 0.529673 & 0.325513 & 0.411801 & 8.745720 & 0.520714 \\
Median & 0.027700 & 0.050600 & 0.473100 & 0.311550 & 0.397100 & 8.716300 & 0.507850 \\
Max. & 0.237300 & 0.367000 & 2.779000 & 0.657200 & 1.042000 & 10.22430 & 1.265000 \\
Min. & -0.083300 & -0.106200 & 0.003700 & 0.083600 & 0.125700 & 7.420100 & 0.138600 \\
Std. Dev. & 0.042147 & 0.072492 & 0.339172 & 0.103615 & 0.147921 & 0.484349 & 0.194477 \\
Skewness & 1.342221 & 0.750084 & 3.478983 & 0.415234 & 1.110473 & 0.569588 & 0.492726 \\
Kurtosis & 7.284298 & 4.866142 & 20.28115 & 3.527843 & 5.030654 & 4.343716 & 3.438650 \\
Jarque- & & & & & & & \\
Bera & 283.3060 & 63.54064 & 3846.488 & 10.73194 & 100.3724 & 34.39484 & 12.89577 \\
$\begin{array}{l}\text { Probability } \\
\text { Sum }\end{array}$ & 0.000000 & 0.000000 & 0.000000 & 0.004673 & 0.000000 & 0.000000 & 0.001584 \\
$\begin{array}{l}\text { Sum Sq. } \\
\text { Dev. }\end{array}$ & 9.083000 & 15.50340 & 140.8929 & 86.58650 & 109.5390 & 2326.361 & 138.5098 \\
Observation & 0.470734 & 1.392596 & 30.48498 & 2.845048 & 5.798337 & 62.16740 & 10.02266 \\
S & 266 & 266 & 266 & 266 & 266 & 266 & 266
\end{tabular}

FATO has a mean value of 53 percent and the turnover ratio has a wide-spread value from the highest of 278 percent to the lowest value of 0.3 percent for the selected period and the median is at the value of 0.473 . The average value for ASTA stands at 32.5 percent, the extreme value recorded at 66 
INTERNATIONAL JOURNAL OF ACADEMIC RESEARCH IN ACCOUNTING, FINANCE AND MANAGEMENT SCIENCES

Vol. 11, No. 1, 2021, E-ISSN: 2225-8329 @ 2021 HRMARS

percent and the lowermost value at 8.4 percent and indicates the huge size of ASTA for construction firms. TATO has a mean of 41 percent with the maximum value 104 percent and the lowest value of 13 percent and shows the low returns obtained from the investments of assets. SIZE is computed by using the logarithm of total assets has a mean value of 8.745720 , the highest value of 10.2243 and a minimum value of 7.4201 and the standard deviation for SIZE stands at 0.484 . FLEV has an average value of 52 percent, with the maximum value of 126 percent and the minimum value of 14 percent.

\section{Correlation Analysis}

From the results, ROA is positively correlated with FATO, TATO and SIZE, while having an inverse association with ASTA and FLEV. The strongest correlation coefficient was between ROA and FLEV at -41 percent. Meanwhile, ROE is negatively correlated to ASTA and FLEV and the other three variables, i.e. FATO, TATO and SIZE are positively correlated with ROE. The strongest link between variables are between ROE and FLEV at -31 percent. In short, both ROA and ROE have a positive correlation with FATO, TATO and SIZE which means that any favourable changes in the variables would have an advantageous impact towards the proxy variables. Any increase in value of ASTA and FLEV would shrink the values of the performance indicators. Table 2 also depicts the correlation coefficients of the variables deliberated in this research. ROA and ROE are positively correlated with all the independent variables, i.e. FATO, ASTO and SIZE. This means that any changes in the stated proxy variables would give rise to a favourable impact towards ROA and ROE. On the other hand, both ASTA and FLEV has a negative correlation with the profitability proxies, thus giving an adverse impact towards both proxies for any change of value in those variables. Hence, from the results, the correlation matrix proposes the presence of sensible association between all variables as no variables in the research are highly associated. 
INTERNATIONAL JOURNAL OF ACADEMIC RESEARCH IN ACCOUNTING, FINANCE AND MANAGEMENT SCIENCES

Vol. 11, No. 1, 2021, E-ISSN: 2225-8329 @ 2021 HRMARS

Table 2: Pearson Correlation Coefficients

\begin{tabular}{|c|c|c|c|c|c|c|c|}
\hline $\begin{array}{l}\text { Correlation } \\
\text { t-Statistic } \\
\text { Probability }\end{array}$ & ROA & ROE & FATO & ASTA & ASTO & SIZE & FLEV \\
\hline \multirow[t]{2}{*}{ ROA } & 1.000000 & & & & & & \\
\hline & ----- & & & & & & \\
\hline \multirow[t]{3}{*}{ ROE } & 0.879765 & 1.000000 & & & & & \\
\hline & 30.06782 & ----- & & & & & \\
\hline & 0.0000 & ----- & & & & & \\
\hline \multirow[t]{3}{*}{ FATO } & 0.070671 & 0.105358 & 1.000000 & & & & \\
\hline & 1.151147 & 1.721447 & ----- & & & & \\
\hline & 0.2507 & 0.0863 & ----- & & & & \\
\hline \multirow[t]{3}{*}{ ASTA } & -0.021889 & -0.091696 & -0.029905 & 1.000000 & & & \\
\hline & -0.355737 & -1.496195 & -0.486115 & ----- & & & \\
\hline & 0.7223 & 0.1358 & 0.6273 & ----- & & & \\
\hline \multirow[t]{3}{*}{ TATO } & 0.129763 & 0.173290 & $0.243652-$ & -0.164942 & 1.000000 & & \\
\hline & 2.126375 & 2.858882 & $4.081901-$ & -2.717200 & ----- & & \\
\hline & 0.0344 & 0.0046 & 0.0001 & 0.0070 & ----- & & \\
\hline \multirow[t]{3}{*}{ SIZE } & 0.191908 & 0.229486 & 0.232008 & 0.241269 & 0.124717 & 1.000000 & \\
\hline & 3.177192 & 3.830941 & 3.875430 & 4.039483 & 2.042354 & ----- & \\
\hline & 0.0017 & 0.0002 & 0.0001 & 0.0001 & 0.0421 & ----- & \\
\hline \multirow[t]{3}{*}{ FLEV } & -0.413124 & -0.311294 & 0.152737 & 0.195281 & 0.011431 & 0.168557 & 1.000000 \\
\hline & -7.370885 & -5.322387 & 2.511142 & 3.235226 & 0.185736 & 2.778487 & ----- \\
\hline & 0.0000 & 0.0000 & 0.0126 & 0.0014 & 0.8528 & 0.0059 & ----- \\
\hline
\end{tabular}

\section{Panel Regression Analysis}

The panel model of regression analysis was used in an attempt to further evaluate the links between the management of non-current assets and the profitability of the firm. In achieving the need, EViews 11 Software was used to analyse panel results for a total of 38 firms from the construction sector in the Bursa Malaysia over a span of seven years from 2011 to 2017. The following is the regression estimation result where the profitability of firms is determined by the ROA and ROE are deliberated by FATO, ASTA, TATO, SIZE and FLEV.

\section{Pooled Ordinary Least Square (OLS) Regression}

Based on the results from Table 3 shows that the independent variables presented about 25.6 percent of the change in ROA that represent the profitability of the firms and points out that ROA is supposed to drop by 0.112486 percent should all variables remain stable and unchanged. 
INTERNATIONAL JOURNAL OF ACADEMIC RESEARCH IN ACCOUNTING, FINANCE AND MANAGEMENT SCIENCES

Vol. 11, No. 1, 2021, E-ISSN: 2225-8329 @ 2021 HRMARS

Table 3: Pooled Ordinary Least Square (OLS) - ROA

\begin{tabular}{crrrr} 
Variable & Coefficient & Std. Error & t-Statistic & Prob. \\
\hline \hline C & $-0.112486 * * *$ & 0.041420 & -2.715745 & 0.0071 \\
FATO & 0.008121 & 0.007082 & 1.146729 & 0.2525 \\
ASTA & 0.012335 & 0.023265 & 0.530204 & 0.5964 \\
TATO & $0.026976^{*}$ & 0.016043 & 1.681416 & 0.0939 \\
SIZE & $0.020610^{* * *}$ & 0.005006 & 4.116665 & 0.0001 \\
FLEV & $-0.101865^{* * *}$ & 0.012030 & -8.467446 & 0.0000 \\
\hline \hline R-squared & 0.255875 & Adjusted R-squared & & 0.241565 \\
S.E. of regression & 0.036705 & F-statistic & & 17.88076 \\
Prob(F-statistic) & 0.000000 & & & \\
\hline \hline
\end{tabular}

***Significant at $1 \%$ level, $* *$ Significant at $5 \%$ level, *Significant at $10 \%$ level.

Table 4: $\quad$ Pooled Ordinary Least Square (OLS)- ROE

\begin{tabular}{crlrl} 
Variable & Coefficient & Std. Error & t-Statistic & Prob. \\
\hline \hline C & $-0.249528 * * *$ & 0.073527 & -3.393672 & 0.0008 \\
FATO & 0.013977 & 0.012571 & 1.111851 & 0.2672 \\
ASTA & -0.047419 & 0.041300 & -1.148176 & 0.2520 \\
TATO & $0.056749 * *$ & 0.028480 & 1.992578 & 0.0474 \\
SIZE & $0.041341 * * *$ & 0.008887 & 4.651690 & 0.0000 \\
FLEV & $-0.132674 * * *$ & 0.021356 & -6.212589 & 0.0000 \\
\hline \hline R-squared & 0.207358 & Adjusted R-squared & & 0.192115 \\
S.E. of regression & 0.065157 & F-statistic & & 13.60342 \\
Prob(F-statistic) & 0.000000 & & \\
\hline \hline
\end{tabular}

***Significant at $1 \%$ level, $* *$ Significant at $5 \%$ level, *Significant at $10 \%$ level.

Table 4 result suggests that the predictor variables represented approximately 20.7 percent of the improvement in ROE, the proxy of profitability for firms and points out that ROE would decrease by 0.249528 percent when all variables remain stable and unchangeable.

\section{Breusch-Pagan Lagrangian Multiplier Test}

Based on Table 5 and 6 , the null hypothesis is rejected at 1 percent significant level. This indicates that the random effect model is more appropriate compared to Pooled ordinary least squares (OLS), because of the presence of error term which is not constant, that will affect the efficiency of the Pooled Model. 
INTERNATIONAL JOURNAL OF ACADEMIC RESEARCH IN ACCOUNTING, FINANCE AND MANAGEMENT SCIENCES

Vol. 11, No. 1, 2021, E-ISSN: 2225-8329 @ 2021 HRMARS

Table 5: Breusch-Pagan (BP) Lagrangian Multiplier Test - ROA

\begin{tabular}{lrrr}
\hline \hline Effects Test & Statistic & d.f. & Prob. \\
\hline \hline Cross-section F & 10.796668 & $(37,223)$ & 0.0000 \\
Cross-section Chi-square & 273.058170 & 37 & 0.0000
\end{tabular}

Table 6: Breusch-Pagan (BP) Lagrangian Multiplier Test - ROE

\begin{tabular}{lrrr}
\hline \hline Effects Test & Statistic & d.f. & Prob. \\
\hline \hline Cross-section F & 5.983749 & $(37,223)$ & 0.0000 \\
Cross-section Chi-square & 183.420408 & 37 & 0.0000 \\
\hline \hline
\end{tabular}

\section{Hausman Test}

From Table 7 and 8, the null hypothesis is rejected because the p-value is statistically significant at 1 percent level. It also means that there is a co-variance between the error term and the regressor, making random effect statistically not efficient. Therefore, the fixed effect model is more appropriate for this study compared to random effect model.

Table 7: Hausman Test -ROA

\begin{tabular}{|c|c|c|c|}
\hline Test Summary & Chi-Sq. Statistic & Chi-Sq. d.f. & Prob. \\
\hline Cross-section random & 17.819519 & 5 & $0.0032 * * *$ \\
\hline
\end{tabular}

Table 8: Hausman Test - ROE

\begin{tabular}{|c|c|c|c|}
\hline Test Summary & Chi-Sq. Statistic & Chi-Sq. d.f. & Prob. \\
\hline Cross-section random & 21.902427 & 5 & $0.0005^{* * *}$ \\
\hline
\end{tabular}

Based on the summaries of the results of panel regression analysis in Table 9 and 10, we find evidence that the best model to explain the empirical research for this study is the fixed effect regression model (FEM). 
INTERNATIONAL JOURNAL OF ACADEMIC RESEARCH IN ACCOUNTING, FINANCE AND MANAGEMENT SCIENCES

Vol. 11, No. 1, 2021, E-ISSN: 2225-8329 @ 2021 HRMARS

Table 9: Summary of the Results of Panel Regression Analysis - ROA

\begin{tabular}{|c|c|c|c|}
\hline ROA & Pooled OLS & REM & FEM \\
\hline$C$ & $\begin{array}{l}-0.112486 \\
-2.715745\end{array}$ & $\begin{array}{l}-0.043816 \\
-0.753056\end{array}$ & $\begin{array}{l}-0.112486 \\
-3.573851\end{array}$ \\
\hline FATO & $\begin{array}{l}0.008121 \\
1.146729 \\
\end{array}$ & $\begin{array}{l}0.035548 \\
3.063745 \\
\end{array}$ & $\begin{array}{c}0.008121^{*} \\
1.908602\end{array}$ \\
\hline ASTA & $\begin{array}{l}0.012335 \\
0.530204\end{array}$ & $\begin{array}{l}-0.007458 \\
-0.268834\end{array}$ & $\begin{array}{l}0.012335 \\
0.758935\end{array}$ \\
\hline TATO & $\begin{array}{l}0.026976 \\
1.681416 \\
\end{array}$ & $\begin{array}{l}0.011996 \\
0.542494 \\
\end{array}$ & $\begin{array}{l}0.026976 \\
1.602369 \\
\end{array}$ \\
\hline SIZE & $\begin{array}{l}0.020610 \\
4.116665 \\
\end{array}$ & $\begin{array}{l}0.010057 \\
1.497186 \\
\end{array}$ & $\begin{array}{c}0.020610 * * * \\
5.180724\end{array}$ \\
\hline FLEV & $\begin{array}{l}-0.101865 \\
-8.467446 \\
\end{array}$ & $\begin{array}{l}-0.060182 \\
-3.911405 \\
\end{array}$ & $\begin{array}{c}-0.101865^{* * *} \\
-7.649170 \\
\end{array}$ \\
\hline Observation & 266 & 266 & 266 \\
\hline LM Test & (REM is I & 0 & \\
\hline Hausman Test & & \multicolumn{2}{|c|}{$\begin{array}{c}17.819519 \\
0.0032^{* * *} \\
\text { FEM is more appropriate }\end{array}$} \\
\hline
\end{tabular}

$* * *$ Significant at $1 \%$ level, $* *$ Significant at $5 \%$ level, $*$ Significant at $10 \%$ level. 
INTERNATIONAL JOURNAL OF ACADEMIC RESEARCH IN ACCOUNTING, FINANCE AND MANAGEMENT SCIENCES

Vol. 11, No. 1, 2021, E-ISSN: 2225-8329 @ 2021 HRMARS

Table 10: Summary of the Results of Panel Regression Analysis - ROE

\begin{tabular}{|c|c|c|c|}
\hline ROE & Pooled OLS & REM & FEM \\
\hline \multirow{2}{*}{ C } & -0.249528 & -0.132510 & -0.249528 \\
\hline & -3.393672 & -1.255476 & -4.474327 \\
\hline \multirow{2}{*}{ FATO } & 0.013977 & 0.053290 & $0.013977^{*}$ \\
\hline & 1.111851 & 2.673277 & 1.786305 \\
\hline \multirow{2}{*}{ ASTA } & -0.047419 & -0.048055 & -0.047419 \\
\hline & -1.148176 & -0.915872 & -1.326735 \\
\hline \multirow{2}{*}{ TATO } & 0.056749 & 0.051961 & $0.056749 *$ \\
\hline & 1.992578 & 1.292417 & 1.914531 \\
\hline \multirow{2}{*}{ SIZE } & 0.041341 & 0.023568 & $0.041341 * * *$ \\
\hline & 4.651690 & 1.909421 & 6.107475 \\
\hline \multirow{2}{*}{ FLEV } & -0.132674 & -0.094698 & $-0.132674 * * *$ \\
\hline & -6.212589 & -3.289297 & -6.320305 \\
\hline Observation & 266 & 266 & 266 \\
\hline LM Test & \multicolumn{2}{|c|}{$\begin{array}{c}183.420408 \\
0.0000 \\
\text { (REM is more appropriate) }\end{array}$} & \\
\hline Hausman Test & & \multicolumn{2}{|c|}{$\begin{array}{l}0.0005 \\
\text { FEM is more appropriate }\end{array}$} \\
\hline
\end{tabular}

$* * *$ Significant at $1 \%$ level, $* *$ Significant at $5 \%$ level, *Significant at $10 \%$ level

Based on the results of this study, both the regression models, i.e. ROA and ROE were having issues with the normality test, i.e. data are not equally distributed, the auto-correlation and heteroscedasticity issues which may lead to underestimates of standard error thus giving a wrong impression and biasness on the significance of variables. Hence, the comparison of an estimates to its standard error would be suggested and that would be using the white diagonal standard errors test and the results being explained below.

The corrected regression model for ROA is estimated as follows:

ROA $=-0.112486+0.008121$ FATO +0.012335 ASTA +0.026976 TATO + 0.020610 SIZE -0.101865 FLEV

This corrected model suggests that the profitability proxy, ROA would be reduced by 0.11 percent should the other independent variables be static or at zero. However, should the other variables, i.e., FATO, ASTA, TATO, SIZE and FLEV change accordingly, it could be estimated that ROA would be increased by 25.6 percent. In short, the independent variables selected statistically would have an impact towards the ROA by up to 24.2 percent. 
INTERNATIONAL JOURNAL OF ACADEMIC RESEARCH IN ACCOUNTING, FINANCE AND MANAGEMENT SCIENCES

Vol. 11, No. 1, 2021, E-ISSN: 2225-8329 @ 2021 HRMARS

\section{Table 11: Corrected Fixed Effect Model of ROA}

\begin{tabular}{crlrl}
\hline \hline Variable & Coefficient & Std. Error & t-Statistic & Prob. \\
\hline \hline C & -0.112486 & 0.031475 & -3.573851 & 0.0004 \\
FATO & $0.008121^{*}$ & 0.004255 & 1.908602 & 0.0574 \\
ASTA & 0.012335 & 0.016253 & 0.758935 & 0.4486 \\
TATO & 0.026976 & 0.016835 & 1.602369 & 0.1103 \\
SIZE & $0.020610^{* * *}$ & 0.003978 & 5.180724 & 0.0000 \\
FLEV & $-0.101865^{* * *}$ & 0.013317 & -7.649170 & 0.0000 \\
\hline \hline R-squared & 0.255875 & Adjusted R-squared & 0.241565 \\
S.E. of regression & 0.036705 & F-statistic & & 17.88076 \\
Prob(F-statistic) & 0.000000 & & & \\
\hline
\end{tabular}

***Significant at $1 \%$ level, ${ }^{* *}$ Significant at $5 \%$ level, *Significant at $10 \%$ level.

Referring to Table 11, it is evident that FATO is positively and significantly has an impact ROA at 10 percent level, i.e., an improvement in FATO by 10 percent, ROA would be favourable by 0.08 percent. This result establishes on the importance of investments in non-current assets as the move would make the firms' shareholders happy with the increment in the return of the assets.

The corrected regression model for ROE is estimated as follows:

ROE $=-0.249528+0.013977$ FATO -0.047419 ASTA +0.056749 TATO + 0.041341 SIZE -0.132674 FLEV.

From Table 12, the R-squared is estimated at 0.1921 after selecting the corrected FEM and designates that 19.2 percent of ROE value would increase triggered by the selected independent variables. Contrarily, should the independent variables remain constant, ROE would be reduced by 0.25 percent. Statistically, should there be any relevant variable is added to the model, the value of Rsquared will be adjusted to 20.74 percent. This model revealed that FATO is predicted to have a positive and influential relationship with ROE at 10 percent significant level. This proposes that ROE would have a desirable impact by 0.014 percent for every 10 percent of increase in FATO. This signifies that the firm's NCA have a significant contribution to the higher generating of revenue flows thus resulting in improving the ROE of the firm. This result is similar to the result attained by Alarussi and Alhaderi (2018), Azad et al. (2018) and Dada and Ghazali (2016), where the FATO is positively and significantly correlated to ROE. Li (2004) suggested that NCA have a negative association with productivity, contrary to other reports. Divergently, Al-Ani (2013) has found out that FATO does not have any impact towards profitability ratios, i.e. ROA and ROE for construction firms in Oman and his results was consistent with lqbal and Mati (2012) conclusion on the NCA do not lead to the increase in ROA and ROE. 
INTERNATIONAL JOURNAL OF ACADEMIC RESEARCH IN ACCOUNTING, FINANCE AND MANAGEMENT SCIENCES

Vol. 11, No. 1, 2021, E-ISSN: 2225-8329 ๔ 2021 HRMARS

Table 12: Corrected Fixed Effect Model of ROE

\begin{tabular}{crrrr}
\hline \hline Variable & Coefficient & Std. Error & t-Statistic & Prob. \\
\hline \hline C & -0.249528 & 0.055769 & -4.474327 & 0.0000 \\
FATO & $0.013977^{*}$ & 0.007825 & 1.786305 & 0.0752 \\
ASTA & -0.047419 & 0.035741 & -1.326735 & 0.1858 \\
TATO & $0.056749^{*}$ & 0.029641 & 1.914531 & 0.0566 \\
SIZE & $0.041341^{* * *}$ & 0.006769 & 6.107475 & 0.0000 \\
FLEV & $-0.132674 * * *$ & 0.020992 & -6.320305 & 0.0000 \\
\hline \hline R-squared & 0.207358 & Adjusted R-squared & 0.192115 \\
S.E. of regression & 0.065157 & F-statistic & & 13.60342 \\
Prob(F-statistic) & 0.000000 & & & \\
\hline \hline
\end{tabular}

$* * *$ Significant at $1 \%$ level, $* *$ Significant at $5 \%$ level, * Significant at $10 \%$ level.

Based on the statistical results, FATO which is used as a measure on the firms' efficiency has influence over the firms' performance. Interestingly, both ROA and ROE has a significant and positive impact towards the change in the FATO. Thus, this first hypothesis $(\mathrm{H} 1)$ is accepted and proves with the ability to improve the FATO, firms' performance in terms of profitability measured using ROA and ROE would increase. From the data gathered, the mean for FATO was approximately 0.54, and this could be an indicator for the firms in the construction sector to further improve their FATO. Since the empirical evidence suggests that FATO has a positive and significant influence on both ROA and ROE as performance indicators, any firms with the ability to further push their FATO would attain better profits. From the results of the study, the average FATO was recorded at approximately 53sen for every RM1 spent on fixed assets. Statistically, the average FATO in the Malaysian construction sector is considered acceptable, as the higher the ratio, the better the assets is being utilised in generating revenue. Since the turnover ratio gauges the efficiency of firms in managing resources to create revenue, obviously high turnover ratio is desired as it shows the state of the firms' business operations. On the other hand, the sector's average ROA is at 3.5sen for every RM1 spent on assets and average ROE is at 5.8sen for every RM1 invested in equity. The notable differences between the profitability proxies (ROA and ROE) average values and the average assets turnover value suggested that firms' in the sector faced fierce pricing competition due to the high escalation of direct material costs and the financing costs used in sourcing out the NCA. This revealed that the low profitable proxies is the consequences for firms to acquire NCA, where higher NCA acquisitions would reflect a desirable high FATO but at the same time reflecting a low ROA and ROE. Thus, it could be concluded that firms with high FATO could afford of having a low ROA and ROE, and firms with low ROA and ROE could not afford to have low FATO. Thus, the result of the study supports the hypothesis FATO has significant impact towards the firms' performance measured by ROA and ROE.

Next, the results from the research revealed that the tangibility of firms' assets has no significant influence towards the firms' performance and both models tested shown that ASTA has a negative coefficient with ROA and ROE. This results interpreted that the tangibility of assets does not have influence on the firms' performance in the construction sector, thus giving valuable information to managers that high ASTA does not guarantee high returns, i.e. by increasing the ASTA percentage to 
INTERNATIONAL JOURNAL OF ACADEMIC RESEARCH IN ACCOUNTING, FINANCE AND MANAGEMENT SCIENCES

Vol. 11, No. 1, 2021, E-ISSN: 2225-8329 ๑ 2021 HRMARS

above the mean value (approx. 32 percent) has no effect towards profitability. The empirical result attained, i.e. ASTA is non influential towards firms' performance, as per inference presented by AlAni (2013), Al-Jafari and Al-Samman (2015) and Do et al. (2020). The outcome of the study rejects the second hypothesis $(\mathrm{H} 2)$ that assets efficiency measured by ASTA has no impact on the firms' profitability. Lastly, the turnover ratio of the entire assets, i.e. TATO statistically bears influence on ROE for the construction firms' performance with a positive note. This vindicates that any change in the overall structure of assets has impact towards the ROE received by construction firms but not for ROA. Despite of having a mixed results on the firms' performance, the improvements in achieving higher TATO by managers should be the main agenda as the significance level of ROE towards TATO was at 10 percent level and could be further enhanced. Hence, for TATO, it can be concluded from the result, the study supports the final hypothesis $(\mathrm{H} 3)$ that TATO has significant impact towards the firms' performance measured by ROE but not for ROA.

\section{Conclusion}

The aim of this study was to analyse the impact of NCA (fixed asset turnover, asset tangibility, and total asset turnover) that are considered relevant to the performance of construction firms' listed on Bursa Malaysia from 2011 to 2017. The findings revealed that FATO has a significant positive impact on both the profitability proxies, i.e. ROA and ROE. This statistically proves that an increase in FATO, the profitability of firms' measured using ROA and ROE would also swell. Interestingly, the results also revealed that ASTA has no significant impact towards the firms' performance indicators in this research, i.e. ROA and ROE. This shows that the tangibility of assets is not a factor in influencing firms' performance as lease of NCA an option for firms not willing or against the idea of NCA possession. On the other hand, TATO have an insignificant impact towards both of the firms' profitability, i.e. ROA but is positively significant with ROE. Remarkably, external financing would be the cause of difference between both profitability proxies results as the average of the Malaysian construction industry leverage is at 52 percent, with the highest leverage recorded at 126.5 percent. The need of high technology NCA in gaining competitive advantage would normally take its toll to the firms in the early stage due to the high capital outlay thus giving rise to the need for some firms to having their operations funded by external parties. Thus, the findings indicate greater confidence in the pecking order theory. This suggests that the relevance of the pecking order theory in the NCA as the option of using debt over the internal funds. If the company's internal resources is limited to the financing of investments and dividends, the company will have access to external funding. Thus, this study confirmed that the external funding priorities will take precedence over the issue of debt in relation to equity.

This study was not without limitations. This study has been focusing on the Malaysian construction firms listed in Bursa Malaysia as a whole, and excluding firms with insufficient financial statements throughout the 7 years of the sampling period. This generalisation ignores the authorised share capital and the issued and paid-up capital of the firms, hence the actual size of the firms based on the share capital are not taken into consideration. For future study, it would be reckoned that construction firms should be categorised based on their value of their authorised, issued and paid up capital so proper comparisons could be made within the same category. The author would also suggest further researchers to make comparison on the firms' performance based on the economic scenario, i.e. boom, crisis, recovery period and such so that the pattern of the firms' performance could be further enhanced based on the economic situation. Further studies could also focus on other 
INTERNATIONAL JOURNAL OF ACADEMIC RESEARCH IN ACCOUNTING, FINANCE AND MANAGEMENT SCIENCES

Vol. 11, No. 1, 2021, E-ISSN: 2225-8329 @ 2021 HRMARS

sectors with high capital intensity such as the manufacturing, transportation and logistics and others and provide significant GDP percentage to Malaysia. This study also did not consider the economic factors giving impact towards the profitability of the selected firms such as GDP, inflations, interest rate and corporate income tax rate. Thus, the outcome from this study portrayed a significant influence towards the internal users of the financial statements rather than the external users. It would be beneficial if the future study would be able to include the external factors mentioned above so that the outcome would be more meaningful. Overall, no doubt that high acquisition and possession of NCA would be desirable to firms as this enable firms to venture and explore new business possibilities that would provide high returns but firms need to be aware that such high NCA possession would come with the price in firms' high gearing. Yes, firms would be able to get new and more financing as the NCA would be able to be used as collateral, entitled to capital allowances in the tax computation, but firms need to be attentive with the globalisation, competitiveness and business uncertainty of the Malaysian construction industry today.

The main contributions of this study include analysing and extending the existing study from a new viewpoint. Firstly, this study extended a significant contribution to the theories i.e. agency theory, trade-offs theory, pecking order theory, stewardship theory, and stakeholder theory. Hence, this work was aimed at inspecting the validity of these hypotheses and devoting the effects of fixed asset turnover, the tangibility of assets, and total asset turnover to the option of debt-equity firms in Malaysia's construction market. Secondly, the findings from this study would offer critical input for the government in developing and updating policies as well as the development of an asset management framework for more to enhance growth and encouraging automation. Thirdly, regulatory bodies such as the Department of Occupational Safety and Health (DOSH), a department under the Ministry of Human Resources can use these findings to enhance the framework for ensuring the safety, health, and welfare of people at work as well as protecting other people from the safety and health hazards arising from the activities in the construction sector. Through this study, the management will be able to strategize and optimize the utilisation of their NCA on achieving the desired profitability and provide handy information for future investors and interested parties keen on contributing their resources, reducing risks in making their investment decisions, and predicting the possible returns gained from the decision. Finally, for the academicians, this study would provide in-depth information by providing important materials and sources for future study in the existing knowledge.

\section{References}

Abdel Shahid, S. F. (2003). Does ownership structure affect firm value? Evidence from the Egyptian stock market. SSRN Electronic Journal. https://doi.org/10.2139/ssrn.378580

Agyei, A., \& Owusu, A. R. (2014). The effect of ownership structure and corporate governance on capital structure of Ghanaian listed manufacturing companies. International Journal of Academic Research in Accounting, Finance and Management Sciences, 4(1), 109-118. https://doi.org/10.6007/ijarafms/v4-i1/547

Al-Ani, M. K. (2013). Effects of assets structure on the financial performance: Evidence from Sultanate of Oman. In Proceedings of the 11th Eurasia Business and Economics Society Conference. Ekaterinburg, Russia, 147-165. 
INTERNATIONAL JOURNAL OF ACADEMIC RESEARCH IN ACCOUNTING, FINANCE AND

MANAGEMENT SCIENCES

Vol. 11, No. 1, 2021, E-ISSN: 2225-8329 @ 2021 HRMARS

Al-Jafari, M. K., \& Al-Samman, H. (2015). Determinants of profitability: Evidence from industrial companies listed on Muscat securities market. Review of European Studies, 7(11), 303-311. https://doi.org/10.5539/res.v7n11p303

Alarussi, A. S., \& Alhaderi, S. M. (2018). Factors affecting profitability in Malaysia. Journal of Economic Studies, 45(3), 442-458. https://doi.org/10.1108/jes-05-2017-0124

Ameh, O. J., Soyingbe, A. A., \& Odusami, K. T. (2010). Significant factors causing cost overruns in telecommunication projects in Nigeria. Journal of Construction in Developing Countries, 15(2), 49-67.

Azad, A. M. S., Raza, A., \& Zaidi, S. S. Z. (2018). Empirical relationship between operational efficiency and profitability (evidence from Pakistan exploration sector). Journal of Accounting, Business and Finance Research, 2(1), 7-11.

Balatbat, M. C., Lin, C., \& Carmichael, D. G. (2010). Comparative performance of publicly listed construction companies: Australian evidence. Construction Management and Economics, 28(9), 919-932. https://doi.org/10.1080/01446193.2010.501805

Blair, M. M. (1995). Rethinking assumptions behind corporate governance. Challenge, 38(6), 12-17. https://doi.org/10.1080/05775132.1995.11471861

Brigham, E. F. (1995). Fundamentals of Financial Management (7th ed.). Dryden Press.

Cannon, J., \& Hillebrandt, P. M. (1989). Theories of the firm. The Management of Construction Firms, 1-8. https://doi.org/10.1007/978-1-349-13626-1_1

Chen, H., C'urdia, V., \& Ferrero, A. (2011). The macroeconomic effects of large-scale asset purchase program. Federal Reserve Bank of New York Staff Reports, 527.

Chiang, Y. H., Chan, P. C., \& Albert, H. C. E. (2002). Capital structure and profitability of the property and construction sectors in Hong Kong. Journal of Property Investment \& Finance, 20(6). https://doi.org/10.1108/14635780210446469

Chowdhury, A., \& Paul Chowdhury, S. (2010). Impact of capital structure on firm's value: Evidence from Bangladesh. Business and Economic Horizons, 3, 111-122. https://doi.org/10.15208/beh.2010.32

CIDB. (2004). Master Plan for Occupational Safety and Health in the Construction Industry 2005-2010. Construction Industry Development Board (CIDB).

Dada, A. O., \& Ghazali, Z. B. (2016). The impact of capital structure on firm performance: Empirical evidence from Nigeria. IOSR Journal of Economics and Finance, 7(4), 23-30. https://doi.org/10.9790/5933-0704032330

Davis, J. H., Schoorman, F. D., \& Donaldson, L. (1997). Toward a stewardship theory of management. Academy of Management Review, 22(1), 20-47. https://doi.org/10.2307/259223

Do, T. K., Lai, T. N., \& Tran, T. T. (2020). Foreign ownership and capital structure dynamics. Finance Research Letters, 36, 101337. https://doi.org/10.1016/j.frl.2019.101337

Ebaid, I. E. (2009). The impact of capital-structure choice on firm performance: Empirical evidence from Egypt. The Journal of Risk Finance, 10(5), 477-487. https://doi.org/10.1108/15265940911001385

Endut, L. R., Akintoye, A., \& Kelly, J. (2009). Cost and time overruns of projects in Malaysia. http://www.irbnet deldatenliconddCLB10633.pdf

Fama, E. F., \& French, K. R. (2002). Testing trade-off and pecking order predictions about dividends and debt. Review of Financial Studies, 15(1), 1-33. https://doi.org/10.1093/rfs/15.1.1

Flanagan, B. (2005). Managing working capital. Business Credit, 107(8), 26-29. 
INTERNATIONAL JOURNAL OF ACADEMIC RESEARCH IN ACCOUNTING, FINANCE AND

MANAGEMENT SCIENCES

Vol. 11, No. 1, 2021, E-ISSN: 2225-8329 @ 2021 HRMARS

Fraser, L., \& Ormiston, A. (2004). Understanding Financial Statements. Pearson Prentice Hall.

Freeman, R. E. (1984). Strategic management: A stakeholder approach. Pitman.

Frimpong, Y., Oluwoye, J., \& Crawford, L. (2003). Causes of delay and cost overruns in construction of groundwater projects in a developing countries: Ghana as a case study. International Journal of Project Management, 21(5), 321-326. https://doi.org/10.1016/s02637863(02)00055-8

Gajfullina, M. M., Nizamova, G. Z., Musina, D. R., \& Alexandrova, O. A. (2017). Formation of strategy of effective management of fixed production assets of oil companies. Proceedings of the International Conference on Trends of Technologies and Innovations in Economic and Social Studies 2017, 38. https://doi.org/10.2991/ttiess-17.2017.32

Harianto, S. (2017). Rasio keuangan dan pengaruhnya terhadap profitabilitas pada bank pembiayaan rakyat syariah. Esensi, 7(1), 41-48. https://doi.org/10.15408/ess.v7i1.4076

Hutchinson, R. W. (1995). The capital structure and investment decisions of the small ownermanaged firm: Some exploratory issues. Small Business Economics, 7(3), 231-239. https://doi.org/10.1007/bf01135368

Iqbal, A., \& Mati, M. (2012). Relationship between non-current assets \& firms profitability. G. University Library of Munich, Trans.

Irman, M., Purwati, A. A., \& Juliyanti. (2020). Analysis on the influence of current ratio, debt to equity ratio and total asset turnover toward return on assets on the otomotive and component company that has been registered in Indonesia stock exchange within 2011-2017. International Journal of Economics Development Research, 1(1), 36-44.

Jamali, D. (2008). A stakeholder approach to corporate social responsibility: A fresh perspective into theory and practice. Journal of Business Ethics, 82(1), 213-231. https://doi.org/10.1007/s10551-007-9572-4

Kebewar, M. (2013). Does debt affect profitability? An empirical study of French trade sector. SSRN Electronic Journal. https://doi.org/10.2139/ssrn.2205794

Li, D. (2004). The implications of capital investments for future profitability and stock returns - An overinvestment perspective. University of California, Berkeley. http://citeseerx.ist.psu.edu/viewdoc/download?doi=10.1.1.616.87\&rep=rep1\&type=pdf

Lzryadnova, O. (2013). Investments in fixed assets in February 2013. http://www.iep.ru/files/RePEc/gai/recdev/ 108lzryadnova.pdf

Mehmet, A., \& Mehmet, I. (2018). Determining the impact of financial characteristics on firm profitability: An empirical analysis on Borsa Istanbul Energy Firms. WSEAS Transactions on Business and Economics, 15, 547- 559.

Myers, S. (1984). Capital structure puzzle. The Journal of Finance, 39(3), 575-592. https://doi.org/10.1111/j.1540-6261.1984.tb03646.x

Myers, S. C. (2001). Capital structure. Journal of Economic Perspectives, 15(2), 81-102. https://doi.org/10.1257/jep.15.2.81

Myers, S. C., \& Majluf, N. S. (1984). Corporate financing and investment decisions when firms have information that investors do not have. Journal of Financial Economics, 13(2), 187-221. https://doi.org/10.1016/0304-405x(84)90023-0

Nguyen, N. (2019). Performance evaluation in strategic alliances: A case of Vietnamese construction industry. Global Journal of Flexible Systems Management, 21(1), 8599. https://doi.org/10.1007/s40171-019-00230-9 
INTERNATIONAL JOURNAL OF ACADEMIC RESEARCH IN ACCOUNTING, FINANCE AND

MANAGEMENT SCIENCES

Vol. 11, No. 1, 2021, E-ISSN: 2225-8329 @ 2021 HRMARS

Nguyen, V. C. (2020). Human capital, capital structure choice and firm profitability in developing countries: An empirical study in Vietnam. Accounting, 127136. https://doi.org/10.5267/j.ac.2019.11.003

Odusanya, I. A., Yinusa, O. G., \& Ilo, B. M. (2018). Determinants of firm profitability in Nigeria: Evidence from dynamic panel models. SPOUDAI Journal of Economics and Business, 68(1), 4358.

Ofori, G. (2000). Challenges of construction industries in developing countries: Lessons from various countries. In 2nd International Conference on Construction in Developing Countries: Challenges Facing the Construction Industry in Developing Countries, 1-13.

Mary, O. I., Okelue, U. D., \& Uche, N. A. (2012). Investment in fixed assets and firm profitability: Evidence from the Nigerian brewery industry. European Journal of Business and Management, 4(20), 10-17.

Onaolapo, A., \& Kajola, O. (2010). Capital structure and firm performance: Evidence from Nigeria. European Journal of Economics, Finance and Administrative Sciences, 25, 75-82.

Padachi, K. (2006). Trends in working capital management and its impact on firms' performance: An analysis of Mauritian small manufacturing firms. International Review of Business Research Papers, 2(2), 45-58.

Pavlik, E. L., Scott, T. W., \& Tiessen, P. (1993). Executive compensation: Issues and research. Journal of Accounting Literature, 12, 131-189.

Popa, A., \& Ciobanu, R. (2014). The financial factors that influence the profitability of SMEs. International Journal of Academic Research in Economics and Management Sciences, 3(4),177-185. https://doi.org/10.6007/IJAREMS/v3-i4/1117

Pouraghajan, A., \& Malekian, E. (2012). The Relationship between capital structure and firm performance evaluation measures: Evidence from the Tehran stock exchange. International Journal of Business and Commerce, 1(9), 166-181.

Putry, N. A. C., \& Erawati, T. (2013). Pengaruh current ratio, total assets turnover, dan net profit margin terhadap return on assets. Jurnal Akuntansi, 1(2), 22-34.

Rahman, I. A., Memon, A. H., \& Abd. Karim, A. T. (2013). Significant factors causing cost overruns in large construction projects in Malaysia. Journal of Applied Sciences, 13(2), 286-293. https://doi.org/10.3923/jas.2013.286.293

Ramamonjiarivelo, Z. (2016). The impact of privatization on efficiency and productivity: The case of US public hospitals. Journal of Health Care Finance, 43(2), 105-123.

Roca-Puig, V., Beltran-Martin, I., Bou-Llusar, J. C., \& Escrig-Tena, A. B. (2008). External and internal labour flexibility in Spain: A substitute or complementary effect on firm performance? The International Journal of Human Resource Management, 19(6), 1131-1151. https://doi.org/10.1080/09585190802051428

Saeedi, A., \& Mahmoodi, I. (2011). Capital structure and firm performance: Evidence from Iranian companies. International Research Journal of Finance and Economics, 70, 21-28.

Shehu, Z., Endut, I. R., Ekintoye, A., \& Holt, G. D. (2014). Cost overrun in the Malaysian construction industry projects: A deeper insight. International Journal of Project Management, 32, 14711480.

Sunjoko, M. I., \& Arilyn, E. J. (2016). Effects of inventory turnover, total asset turnover, fixed asset turnover, current ratio and average collection period on profitability. Jurnal Bisnis dan Akuntansi, 18(1), 79-83. https://doi.org/10.34208/jba.v18i1.40 
INTERNATIONAL JOURNAL OF ACADEMIC RESEARCH IN ACCOUNTING, FINANCE AND

MANAGEMENT SCIENCES

Vol. 11, No. 1, 2021, E-ISSN: 2225-8329 @ 2021 HRMARS

Warrad, L., \& Rania, A. O. (2015). The impact of turnover ratios on Jordanian services sectors' performance. Journal of Modern Accounting and Auditing, 11(2), 77-85. https://doi.org/10.17265/1548-6583/2015.02.001

Worren, N., Moore, K., \& Cardona, P. (2002). Modularity, strategic flexibility, and firm performance: A study of the home appliance industry. Strategic Management Journal, 23(12), 1123-1140. https://doi.org/10.1002/smj.276

Zahra, S. A., Hayton, J. C., Neubaum, D. O., Dibrell, C., \& Craig, J. (2008). Culture of family commitment and strategic flexibility: The moderating effect of stewardship. Entrepreneurship Theory \& Practice, 32(6), 1035-1054.

Zeitun, R., \& Tian, G. G. (2007). Capital structure and corporate performance: Evidence from Jordan. Australasian Accounting Business and Finance Journal and Authors, 1(4), 1-36. https://doi.org/10.2139/ssrn.2496174 